\author{
dr Ewa JASTRZĘBSKA \\ Kolegium Ekonomiczno-Społeczne, Szkoła Główna Handlowa w Warszawie \\ e-mail: ewa.jastrzebska@sgh.waw.pl
}

DOI: $10.15290 /$ ose.2017.04.88.09

\title{
SPÓJNOŚĆ SPOLECZNA W KONTEKŚCIE SPOŁECZNEJ ODPOWIEDZIALNOŚCI PRZEDSIĘBIORSTW. DEFINIOWANIE, POMIAR I DOBRE PRAKTYKI BIZNESU
}

\begin{abstract}
Streszczenie
Spójność społeczna (SC) nie powinna polegać tylko na przeciwdziałaniu i zmniejszaniu ubóstwa i wykluczenia społecznego poprzez zapewnienie społecznej inkluzji grup zmarginalizowanych i zagrożonych marginalizacja (jak głosily, dominujące do niedawna, wąskie interpretacje tego pojęcia). Jej istotą jest bowiem poprawa jakości życia dzięki tworzeniu poczucia wspólnoty w społeczeństwie (zgodnie ze współczesnym, szerokim ujmowaniem SC). Wielowymiarowość pojęcia SC skutkuje brakiem jednolitego podejścia do jego pomiaru - poziom SC mierzy się zarówno za pomocą wskaźników odnoszących się wyłącznie do nierówności dochodowych, jak i syntetycznych indeksów, jednak coraz bardziej rozbudowywanych. Na spójność społeczną wpływa wiele elementów związanych z rozwojem zrównoważonym, tym samym koncepcja społecznej odpowiedzialności biznesu (CSR), będąca realizacją tego paradygmatu w skali mikro, dotyczy SC. Potwierdza to analiza 667 dobrych praktyk zgłoszonych do raportu Odponviedzialny biznes w Polsce. Dobre praktyki 2016 - przedsiębiorstwa wdrażające CSR podejmują różnorodne działania, które przyczyniają się do wspierania SC.
\end{abstract}

Słowa kluczowe: spójność społeczna, CSR, dobre praktyki, wskaźniki, przedsiębiorstwo, jakość życia

\section{SOCIAL COHESION AND CORPORATE SOCIAL RESPONSIBILITY: DEFINING, MEASURING, GOOD BUSINESS PRACTICES}

\section{Summary}

Social cohesion (SC) should not only rely on preventing and reducing poverty and social exclusion by ensuring the social inclusion of marginalized groups, as was considered until recently. In accordance with the modern, wide interpretation of SC, its purpose is to improve quality of life by creating a sense of community in society. The multi-dimensionality of SC results in the lack of a uniform approach to measuring it. SC is measured both by indicators relating to income inequality, as well as synthetic, although increasingly elaborate indexes. Many elements related to sustainable development have an effect on SC. Thus the concept of corporate social responsibility (CSR), which is the implementation of sustainable development on a micro-scale, also applies to SC. This is confirmed by an analysis of the 667 of good practices included in the Report Responsible Business in Poland 2016. Good Practices. Companies implementing CSR take a variety of actions contributing to the strengthening of SC.

Key words: social cohesion, CSR, good practices, indicators, company, quality of life

JEL classification: M14, E23, I3 


\section{Wstęp}

Nierówności społeczne wydają się być immanentną konsekwencją procesów rozwojowych. Jednak na skutek postępującej globalizacji, nasilających się negatywnych megatrendów, dysproporcje społeczne stają się coraz bardziej wielowymiarowe i dotkliwe. W związku z tym, że ewoluują mechanizmy nierówności, równocześnie zmienia się ich społeczna percepcja i legitymizacja. Bezpośrednią konsekwencją nierówności społecznych jest wykluczenie na różne sposoby coraz większej liczby osób oraz pogłębiająca się polaryzacja świata, regionów, społeczeństw.

Współcześnie problem nierówności coraz częściej rozpatruje się nie tylko w kategoriach sprawiedliwości społecznej, zapewniającej stabilność polityczną danego państwa, lecz również w kontekście barier społeczno-gospodarczych skutkujących negatywnymi konsekwencjami w skali globalnej [Krzyminiewska, 2013, s. 50]. Zapewnienie spójności społecznej (social cohesion - SC) wiąże się z koniecznościa niwelowania dysproporcji. Coraz istotniejszą rolę w tym procesie przypisuje się biznesowi, który postrzega się jako jeden z głównych sprawców zagrożeń globalnych.

W niniejszym artykule podjęto próbę zdefiniowania pojęcia SC w kontekście sposobów jego pomiaru (przy wykorzystaniu analizy desk i web research). Na tym tle przedstawiono sposób podejścia do kwestii SC w koncepcji społecznej odpowiedzialności przedsiębiorstw (corporate social responsibility - CSR), także dzięki zaprezentowaniu dobrych praktyk biznesowych w tym zakresie (studia przypadków).

\section{Spójność społeczna - ujęcie teoretyczne i praktyczne}

Pojęcie spójności społecznej (SC) pojawiło się dopiero w latach dziewięćdziesiątych $\mathrm{XX}$ wieku (autorem jednej z pierwszych prac na ten temat był brytyjski socjolog Ray Pahl [1991]), ale początków tej idei można doszukać się dużo wcześniej, np. już w pracach Emila Durkheima dotyczących solidarności (De la division du travail social, 1893) ${ }^{1}$ bądź późniejszych: Johna Rawlsa - dotyczących sprawiedliwości (A Theory of Justice, 1971) ${ }^{2}$, Norberta Eliasa - więzi (Die Gesellschaft der Individuen, 1987) ${ }^{3}$ czy wreszcie Dicka Stanleya - przynależności [2003].

Współcześnie można rozróżnić dwa główne dyskursy w podejściu do tej idei. W dominującej do niedawna, waskiej interpretacji SC to zmniejszanie różnic w dostępie jednostek do rynku pracy i redukcja ubóstwa, a zarazem zmniejszanie nierówności między grupami społecznymi oraz wykluczenia społecznego. Takie podejście można zaobserwować w polityce spójności Unii Europejskiej, która skupia się na kwestiach związanych z: bezrobociem, ubóstwem i wykluczeniem (także cyfrowym). Spójność spoleczna jest zapisana w art. 3 ust. 3 Traktatu o Unii Europejskiej (W spiera spójność gospodarczq spoteczna $i$ terytorialnq oraz solidarność miedsy Państwami Cžtonkowskimı) oraz art. 174

\footnotetext{
Wydanie polskie: [Durkheim, 2011].

Wydanie polskie: [Rawls, 2009].

Wydanie polskie: [Elias, 2008].
} 
Traktatu o funkcionowaniu Unii Europejskiej (W celu wspierania harmonijnego rozwoju catej Unii

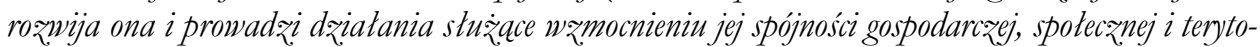
rialnej) ${ }^{4}$. Także strategia „Europa 2020” na rzecz inteligentnego i zrównoważonego rozwoju sprzyjającego włączeniu społecznemu wśród priorytetów rozwojowych dla całej Unii Europejskiej wskazuje zapewnienie SC (poprzez działania na rzecz: zatrudnienia, nabywania umiejętności i walki z ubóstwem) [Komunikat Komisji..., 2010]. Zatem unijna interpretacja SC ściśle wynika z najważniejszych wyzwań społecznych, przed jakimi stoi Wspólnota i ma służyć integracji europejskiej. Podobne podejście w naturalny sposób (jako w państwie członkowskim) dominuje w polskiej polityce. Celem głównym, przyjętej w lutym 2017 roku, Strategii na reecz. Odponviedzialnego Rozwoju jest tworzenie warunków wzrostu dochodów mieszkańców Polski przy jednoczesnym wzroście spójności w wymiarze: społecznym, ekonomicznym, środowiskowym i terytorialnym. Spójność społeczna jest jednym $z$ dwóch obszarów wyróżnionych w ramach celu szczegółowego II Rozuój społecznie wrą̧liny i terytorialnie zrównoważony. Cel ten będzie monitorowany za pomocą wskaźników dotyczących: zatrudnienia, ubóstwa, starzenia się, ale i mieszkalnictwa oraz instytucjonalnej opieki nad dziećmi [Strategia na rzecz..., 2017].

Obecnie coraz częściej SC ujmuje się szerzej, podkreślając zależność między SC a jakościa życia. Zgodnie z taką interpretacją, SC to zdolność społeczeństwa do zapewnienia dobrobytu wszystkim swoim członkom, przy jednoczesnym minimalizowaniu wewnętrznego zróżnicowania oraz unikaniu zjawiska polaryzacji [Greta, Tomczak-Woźniak, 2013, s. 6]. Podobną definicję SC przyjęła Fundacja Inicjatyw Społeczno-Ekonomicznych (za Zrewidowaną Strategią Spójności Społecznej Rady Europy5), uznając, że SC to możliwość zapewniania przez społeczeństwo stosunkowo wysokiej jakości życia swoim członkom oraz zmniejszanie różnic pomiędzy standardami i unikanie nierówności społecznych [Spójność społeczna...]. W kontekście zagrożeń dla SC, Rada Europy podkreśla znaczenie politycznej i obywatelskiej partycypacji. W innym, jeszcze dalej idącym ujęciu (badanie Fundacji Bertelsmanna), SC jest definiowana w kategoriach współpracy społecznej i jest charakteryzowana przez: stosunki społeczne, więzi ze zbiorowością oraz działanie na rzecz dobra wspólnego. Spójność społeczna odnosi się zatem do jakości zbiorowości (społeczności, społeczeństw), a nie jednostek - zbiorowość może być mniej lub bardziej spójna, co dla poszczególnych jednostek może oznaczać wzrost lub spadek poziomu dobrobytu [Social cohesion and well-being..., 2014, s. 6].

Podobną definicję SC, bazującą na interakcjach pomiędzy członkami społeczeństwa, zaproponowali: Joseph Chan, Ho-Pong To i Elaine Chan, uwzględniając w niej kwestie, takie jak: zaufanie, poczucie przynależności, skłonność do partycypacji i pomocy [Chan, To, Chan, 2006]. Interpretowanie SC w kategoriach więzi społecznych

4 Wersje skonsolidowane obu dokumentów zostały opublikowane 7 czerwca 2016 roku w Dzienniku Urzędowym Unii Europejskiej 2016/C 202.

5 W tym dokumencie przyjęto, że: social cohesion is the capacity of a society to ensure the welfare of all its members, minimizing disparities [Concerted Development..., 2005 s. 15]. 
jest charakterystyczne dla Kanady ${ }^{6}$ (a wynika z chęci integracii wielokulturowej społeczeństwa). Jako przykład można przytoczyć prace Jane Jansen, która wyróżniła pięć wymiarów spójności, takich jak:

- przynależność, wynikającą z poczucia tożsamości;

- integracja, wynikająca z równego dostępu,

- partycypacja (uczestnictwo),

- tolerancja dla różnorodności,

- legitymizacja, oznaczająca respektowanie reguł i instytucji.

Do tej klasyfikacji Paul Bernard dodał jeszcze jedną kategorię - równość (przede wszystkim w sensie funkcjonalnym) [Golinowska, 2011, s. 14].

Przyglądając się podejściu kanadyjskiemu, warto zwrócić uwagę także na publikacje Social Cohesion Network. W 1996 roku organizacja ta zdefiniowała SC jako proces umożliwiający społeczeństwu funkcjonowanie dzięki zapewnieniu warunków wstępnych dla wszystkich głównych procesów społecznych. W 2002 roku przyjęła zaś, że SC opiera się na chęci jednostek do współpracy i wspólnego działania na wszystkich poziomach społeczeństwa w celu osiagnięcia wspólnych celów, a zatem uznała współpracę za fundament SC [Jeannotte i in. 2002, s. 2-3].

\section{Kategorie składowe różnych definicji spójności społecznej (szerokie ujęcie pojęcia)}

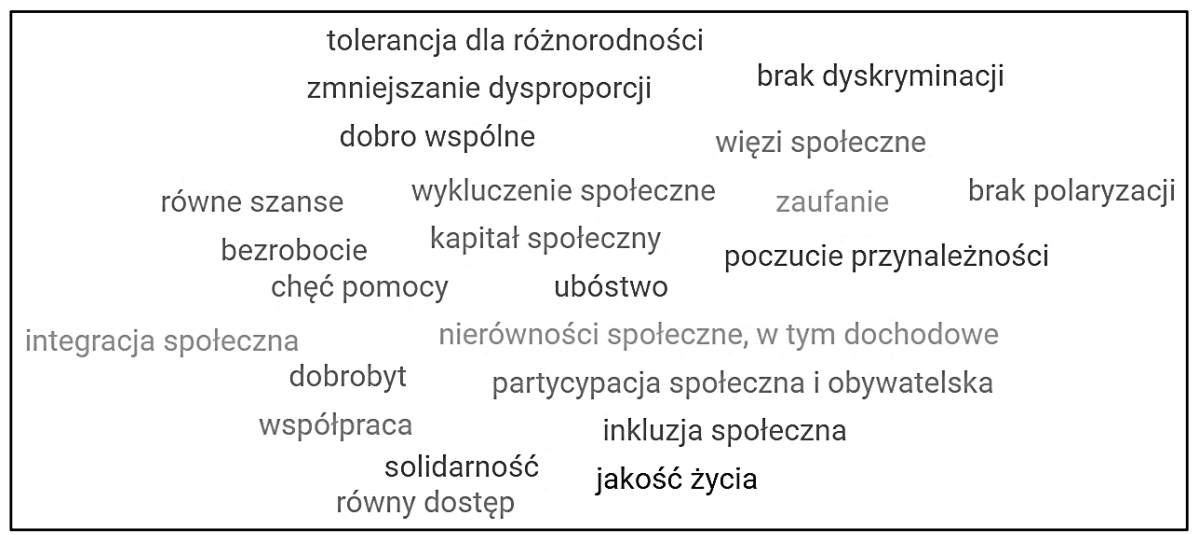

Źródło: opracowanie własne.

Analizując szerokie interpretacje SC, warto również przytoczyć definicję stosowaną w Programie EUROsociAL, kierowanym przez Komisję Europejską do Ameryki Łacińskiej (przy czym trzeba podkreślić, że Unia Europejska właściwie nie wypracowała jednolitej i oficjalnej definicji SC). W EUROsociAL przyjęto, że SC wiąze się z dobrobytem, opartym na równych szansach, poczuciu przynależności i solidarności, a cechuje

6 Senat Kanady zdefiniowal SC jako: the capacity of citizens living under different social or economic circumstances to live together in harmony, with a sense of mutual commitment [Concerted Development..., 2005 s. 26]. 
społeczeństwa jednoczące się wokół wspólnych działań. Spójność społeczną wspierają polityki publiczne w zakresie: przeciwdziałania dyskryminacji (w korzystaniu z praw i dostępie do usług), zmniejszania dysproporcji, zapewniania równych szans i ochrony najsłabszych grup, a także silne ramy instytucjonalne [Social cohesion].

Podsumowując prowadzone rozważania, należy zatem stwierdzić, że SC nie powinna polegać tylko na przeciwdziałaniu i zmniejszaniu ubóstwa i wykluczenia społecznego poprzez zapewnienie społecznej inkluzji grup zmarginalizowanych i zagrożonych marginalizacją (głównie dzięki działaniom w ramach rynku pracy). Jej istota jest bowiem poprawa jakości życia przez tworzenie poczucia wspólnoty w społeczeństwie. Biorąc zaś pod uwagę to, że współcześnie pojęcie jakości życia uwzględnia coraz więcej składowych [Papuć, 2011, s. 142-144], rozszerzeniu ulega równocześnie sama kategoria SC, stając się pojęciem wielowymiarowym, coraz trudniejszym do uchwycenia, ale zarazem nadrzędnym i inteligentnym (smart) [Social cohesion]. Różne kategorie, wpisujące się w pojęcie SC, zaprezentowano na rysunku 1.

\section{Pomiar spójności społecznej}

Wielowymiarowość pojęcia SC skutkuje brakiem jednolitego podejścia do jego pomiaru. Poziom SC można mierzyć zarówno za pomocą np. stopy bezrobocia czy współczynnika Giniego (odnoszącego się wyłącznie do nierówności dochodowych), jak i syntetycznych indeksów. W Unii Europejskiej wskaźniki w zakresie SC powstały i ewoluowały wraz z praktyką prowadzenia polityki spójności. Unia Europejska przyjęła pierwszy wspólny zestaw 18 wskaźników (podstawowych i dodatkowych) związanych z ubóstwem i wykluczeniem społecznym w 2001 roku w Laeken aby monitorować realizację Strategii Lizbońskiej. Dotyczyły one przede wszystkim: poziomu bezrobocia, zagrożenia ubóstwem i rozkładu dochodów [Kosiel, 2012, s. 32-34]. Cele społeczne strategii „Europa 2020” sprawiły, że katalog wskaźników objął również kwestie, takie jak: niska intensywność pracy w gospodarstwie domowym oraz pogłębiona deprywacja materialna [Gábos, Goedemé, 2016]. Zestaw wskaźników społecznych ulega zatem rozszerzeniu, co ze względu na wielowymiarowość SC wydaje się zasadne. Prawidłowość tę można także dostrzec, analizując pojawiające się indeksy złożone dotyczące SC.

Od 2010 roku ONZ publikuje Wskaźnik Rozwoju Społecznego uwzględniający nierówność (Inequality-Adjusted Human Development Index - IHDI) oraz Wskaźnik Wielowymiarowego Ubóstwa (Multidimensional Poverty Index - MPI). IHDI, podobnie jak HDI (Human Development Index), mierzy osiagnięcia danego kraju w trzech wymiarach, takich jak: zdrowie (oczekiwana długość życia), wykształcenie (średnia liczba lat edukacji dla dorosłych i oczekiwana liczba lat edukacji dla dzieci) oraz poziom dochodów (dochód narodowy brutto na mieszkańca według parytetu siły nabywczej waluty), ale uwzględnia także to, jaki jest rozkład tych cech. Im większe nierówności w społeczeństwie, tym niższy jest IHDI od HDI (oba przyjmują wartości od 0 do 1 , gdzie 1 jest wartością maksymalną). Z kolei MPI, liczony dla krajów rozwijających się, pokazuje odsetek ludzi w znacznym stopniu dotkniętych ubóstwem w wymiarach analizowanych przez HDI. Polska, z HDI wynoszącym 0,855 w 2015 roku (36. miejsce na świecie) oraz IHDI równym 0,774 , zalicza się do krajów o bardzo wysokim poziomie rozwoju 
społecznego. Pierwsze miejsce w rankingu od kilkunastu lat należy do Norwegii (w 2015 roku HDI na poziomie 0,949, a IHDI - 0,898) [Human Development...].

Indeks Sprawiedliwości Społecznej dla krajów Unii Europejskiej Fundacji Bertelsmanna (EU Social Justice Index) jest średnią ważoną czterdziestu wskaźników (ilościowych i jakościowych), obejmujących sześć wymiarów, takich jak: ubóstwo, edukacja, rynek pracy, SC i niedyskryminacja (mierzone przyjęciem polityk w zakresie: SC, przeciwdziałania dyskryminacji i integracji oraz współczynnikiem Giniego, równością płci w parlamencie i NEET ${ }^{7}$ ) oraz zdrowie i sprawiedliwość międzypokoleniowa. Pierwsze miejsca w rankingu w 2016 roku należały do: Szwecji $(7,51)$, Finlandii i Danii, natomiast na 4. pozycji znalazły się Czechy (indeks przyjmuje wartości w przedziale 1-10, gdzie 10 oznacza najlepszy wynik). Polska zajęła 15. miejsce z wynikiem 5,81 tuż powyżej średniej unijnej 5,75 (najgorszy wynik notując w obszarze zdrowia), zaś ostatnie miejsce przypadło Grecji $(3,66)$. W latach 2008-2016 wartość indeksu zmalała w przypadku 14 krajów (co przełożyło się na spadek średniej unijnej), zaś największy wzrost indeksu odnotowała Polska (o 27\% i awans z przedostatniego miejsca w rankingu w 2008 roku) [Schraad-Tischler, Schiller, 2016].

W innym badaniu Fundacji Bertelsmanna nad SC (Social Cohesion Radar) analizą objęto 34 wybrane państwa Unii Europejskiej i OECD oraz lata 1989-2012. W badaniu przyjęto, że poziom SC znajduje odzwierciedlenie w postawach i zachowaniach osób oraz grup tworzacych dane społeczeństwo, zatem analizom poddano czynniki, takie jak: relacje społeczne, zaufanie, akceptacja różnorodności, identyfikacja z krajem, zaufanie do instytucji, percepcja sprawiedliwości, solidarność i pomoc, poszanowanie norm społecznych oraz partycypacja obywatelska. Badania dowiodły, że większy poziom dobrobytu przekłada się na większą SC, zaś w przypadku zróżnicowania dochodowego korelacja jest odwrotna. Natomiast jeszcze większy pozytywny wpływ na SC niż dobrobyt ma poziom rozwoju społeczeństwa informacyjnego, wyrażony wskaźnikiem wiedzy Banku Światowego (Knowledge Index), mierzącym: tworzenie, zastosowanie i dyfuzję wiedzy [Social Cohesion Radar...]. Liderami Social Cohesion Radar zostały kraje skandynawskie, zaś większość krajów Europy Zachodniej osiagnęła średni poziom spójności. Polskę, podobnie jak inne kraje Europy Środkowo-Wschodniej, cechowała niska SC, przy czym najwyższy wynik Polska otrzymała w kategorii poczucia tożsamości narodowej, najniższy - partycypacji obywatelskiej [Poland].

Związek między SC a dobrobytem niemal za pewnik przyjęto także w Diagnozie Spotecznej 2015: im mniej wykluczonych, im lepsza integracja społeczna, tym silniejsza wspólnota [Diagnoza społeczna..., 2015, s. 431] ('niemal', gdyż integracja jest jedną z kategorii składowych SC). Spójne (w tym zintegrowane) społeczności są bowiem czymś więcej niż sumą indywidualnych osób - są wspólnota, w ramach której mogą przezwyciężyć wiele trudności i kryzysów [Golinowska, 2011, s. 13].

Parafrazując Dariusza Waldzińskiego, można przyjąć, iż istotą SC jest wszelka aktywność mająca na celu przeciwstawianie się dysproporcjom w rozwoju cywilizacyjnym [Waldziński, 2008, s. 12]. Współcześnie dysproporcje ulegaja poszerzeniu i pogłębieniu, stąd konieczne jest rozwijanie i doskonalenie także metod pomiaru tych zjawisk, aby

NEET (not in employment, education or training) to nazwa zarówno dla zjawiska socjologicznego, jak i grupy społecznej obejmującej młodych ludzi, którzy nie uczą się, nie pracują i nie przygotowują się do zawodu. 
możliwe było kompleksowe, wiarygodne i czytelne mierzenie SC, uwzględniające różnorodność kategorii składowych tego pojęcia. Spójność społeczna powinna bowiem odpowiadać na wyzwania dotyczące gwałtownego rozwoju współczesnego świata i pojawiającymi się w związku z tym zagrożeniami dla społeczeństw.

\section{Spójność społeczna a rozwój zrównoważony i CSR}

Jak wynika z przeprowadzonych rozważań, na SC wpływa wiele elementów związanych z rozwojem zrównoważonym. Rozwój zrównoważony to taki rozwój, który zaspokaja potrzeby obecne, nie pozbawiając przyszłych pokoleń możliwości zaspokojenia ich potrzeb w trzech aspektach, tj.: gospodarczym, społecznym i środowiskowym [Nasza wspólna..., 1991, s. 67]. W „Agendzie 2030” przyjętej przez ONZ w 2015 roku stwierdzono: zrónnoważony rozwój zak łada, że eliminacja ubóstwa we wssystkich jego formach $i$ uymiarach, zwalczanie nierówności wewnatrz i pomiedsy krajami, ochrona naszej planety, dażenie do trwatego $i$ zrónnowa żonego wrrostu gospodarczego sprayjajacego właczeniu społecznemu oraz. wspieranie integragi spotecznej sa ze soba połaczone i wspótzaležne [Przelesztatcamy nasz..., 2015, s. 5]. Wśród zapisanych w Agendzie 17 Celów Zrównoważonego Rozwoju (Sustainable Development Goals SDGs) do kategorii składowych pojęcia SC odnosi się dziesięć następujących celów: 1. koniec z ubóstwem; 2. zero głodu; 3. dobre zdrowie i jakość życia; 4. dobra jakość edukacji; 5. równość płci; 6. czysta woda i warunki sanitarne; 8. wzrost gospodarczy (inkluzywny, gwarantujący pełne zatrudnienie) i godna praca; 10. mniej nierówności; 11. zrównoważone miasta i społeczności (sprzyjające włączeniu społecznemu); 16. pokój, sprawiedliwość i silne instytucje (sprzyjające włączeniu społecznemu) [Cele i Zadania...]. Pojęcie SC literalnie pojawia się w „Agendzie 2030” tylko w jednym miejscu (Będziemy wspótpracować z lokalnymi wtadzami i spotecznościami, aby odnawriá i planować nasze miasta i osiedla

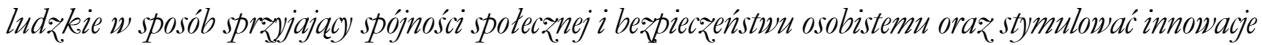
$i$ zatrudnienie) [Pržeksztatcamy nasz..., 2015, s. 10]. Jednak dokument często przywołuje różne kategorie składowe wpisujące się w pojęcie SC (oprócz tych, do których ściśle odnosza się SDGs, także inne, jak np.: integracja społeczna, partycypacja, solidarność, dobrobyt). Na potrzeby monitorowania SDGs został opracowany zestaw wskaźników obecnie jest ich 232 (zrewidowaną listę przyjęto w marcu 2017 roku), ale katalog jest otwarty i ulega modyfikacjom [Revised list...].

W „Agendzie 2030” wymieniono biznes i sektor prywatny wśród interesariuszy, którzy powinni zaangażować się w realizację tego dokumentu. Wezwano także przedsiębiorstwa do wykorzystywania ich kreatywności i innowacji do rozwiązywania problemów rozwoju zrównoważonego [Præęesztatcamy nasz..., 2015, s. 14, 33]. Paradygmat rozwoju zrównoważonego jest jednak koncepcja globalną, odnoszącą się do systemów na poziomie makro (regionów, państw i gospodarek). Jak podkreśla międzynarodowa norma społecznej odpowiedzialności ISO26000, aby maksymalizować wkład na rzecz rozwoju zrównoważonego, przedsiębiorstwa powinny wdrażać koncepcję społecznej odpowiedzialności (CSR), która skupia się na organizacji (wymiar mikro). Celem rozwoju zrównoważonego jest bowiem zapewnienie globalnemu społeczeństwu stabilnych i trwałych warunków istnienia, nie zaś stabilności i trwałości konkretnej organizacji 
[Norma PN-ISO 26000..., 2012, s. 21]. W związku z narastającymi zagrożeniami globalnymi i rosnąca rolą sektora biznesu, przedsiębiorstwa powinny uzupełniać, a nawet w pewnym stopniu zastępować, aktywność państwa, którego rola w dobie globalizacji zmienia się (a zdaniem wielu badaczy - słabnie) [Państwo w teorii..., 2009]. Idea wielopoziomowego i wielopartnerskiego zarządzania w sektorze publicznym (multi-levelgovernance) zakłada współpracę i współodpowiedzialność wszystkich interesariuszy (aktorów polityki rozwoju) w realizowaniu zadań publicznych i rozwiązywaniu problemów społecznych [The White Paper...].

ISO26000 definiuje społeczną odpowiedzialność jako: odpowiedzialność organizaciji za

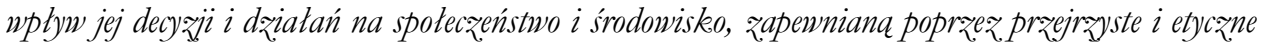
zachowanie, które praycsynia sie do zrónnoważonego rozwoju, w tym dobrobytu $i$ zdrowia spoteczeństwa, uñglednia oczekiwania interesariuszy, jest zgodne z majacym zastosowanie prawem $i$ spójne z. miedsynarodonymi normami postepowania oraz jest zintegrowane z driataniami organizacij i praktykowane w jej relacjach [Norma PN-ISO 26000..., 2012, s. 16]. ISO26000 nie odwołuje się w sposób literalny do SC, jednak tego pojęcia (w jego szerokim rozumieniu) dotyczą cztery z siedmiu kluczowych obszarów społecznej odpowiedzialności wskazanych w tej normie:

- prawa człowieka - obejmuja zapewnienie praw obywatelskich i politycznych (w tym prawa do: życia i wolności, równego traktowania) oraz praw: gospodarczych, społecznych i kulturalnych (w tym prawa do: pracy, wyżywienia, edukacji, bezpieczeństwa socjalnego, standardów w zakresie zdrowia);

- $\quad$ praktyki z zakresu pracy - w tym: zdrowie, BHP, warunki pracy, wynagrodzenie;

- $\quad$ zagadnienia konsumenckie - $\mathrm{w}$ tym związane z projektowaniem produktów i usług, do których mogą mieć dostęp wszyscy oraz umożliwianiem dostępu do nich odbiorcom zagrożonym marginalizacja;

- zaangażowanie społeczne i rozwój społeczności lokalnej - związane ze wzmacnianiem społeczeństwa obywatelskiego także poprzez współpracę ze stowarzyszeniami działającymi na rzecz dobra wspólnego oraz z wkładem w rozwój społeczności lokalnej na rzecz poprawy jej jakości życia (dobrostanu) [Norma PN-ISO 26000..., 2012, s. 31-83].

Przedsiębiorstwa mają do swojej dyspozycji wiele narzędzi i inicjatyw, doprecyzowujących i ułatwiających wdrażanie koncepcji społecznej odpowiedzialności. Wśród nich najbardziej uznanym standardem dotyczącym zrównoważonego raportowania (tj. raportowania na temat ekonomicznego, środowiskowego i społecznego wpływu powodowanego przez codzienną działalność organizacji) sa Wytycz̨ne Global Reporting Initiative (GRI) ${ }^{8}$. Podobnie jak ISO26000, Wytyczne GRI nie odwołują się w sposób bezpośredni do pojęcia SC, ale jak najbardziej dotyczą zagadnień związanych z tą kwestią.

Według GRI G4 jedną z czterech zasad definiowania treści raportu jest kontekst zrównoważonego rozwoju. Zasada ta oznacza, że podstawowym pytaniem, na jakie powinien odpowiadać raport CSR, jest, w jaki sposób przedsiębiorstwo przyczynia się lub zamierza przyczynić się w przyszłości do poprawy lub pogorszenia warunków: eko-

8 Obecnie obowiązuje wersja Wytycznych GRI G4 (do końca czerwca 2018 roku), choć w 2016 roku została opublikowana najnowsza edycja wytycznych - Standardy GRI, nawiązujące do SDGs. 
nomicznych, środowiskowych i społecznych, procesów i perspektyw rozwoju na poziomie: lokalnym, regionalnym lub globalnym [Zasady raportowania..., s. 17]. Wśród wskaźników szczegółowych, charakteryzujących oddziaływanie przedsiębiorstwa na społeczeństwo, w GRI G4 wyodrębniono cztery podkategorie, z których trzy dotyczą zagadnień związanych ze spójnością społeczną:

- praktyki zatrudniania i godnej pracy - podkategoria obejmuje wskaźniki odzwierciedlające kwestie, takie jak np.: zatrudnienie, BHP, szkolenia i edukacja, różnorodność i równość szans, równość wynagrodzenia kobiet i mężczyzn, ocena dostawcy pod kątem praktyk zatrudniania;

- $\quad$ prawa człowieka - wskaźniki w tej podkategorii dotyczą m.in.: niedyskryminowania, pracy przymusowej lub obowiązkowej oraz pracy dzieci, praktyk w zakresie bezpieczeństwa, praw ludności rdzennej, oceny dostawcy w zakresie poszanowania praw człowieka;

- $\quad$ społeczeństwo - podkategoria zawiera wskaźniki dotyczące np.: społeczności lokalnych, zasad związanych z udziałem w życiu publicznym, zgodności z regulacjami, oceny dostawcy ze względu na kwestie społeczne [Zasady raportowania..., s. 64-83].

Kategoria społeczna wskaźników nie jest jedyna, która odnosi się do SC. Wśród wskaźników ekonomicznych także można odnaleźć aspekty powiązane z tym pojęciem, np. wskaźnik ,stosunek wynagrodzenia pracowników najniższego szczebla w podziale na płeć w stosunku do płacy minimalnej na danym rynku w głównych lokalizacjach prowadzenia działalności” czy wskaźnik „bezpośrednia wartość ekonomiczna wytworzona i podzielona", który wiąże się także z wynagrodzeniami i świadczeniami pracowniczymi [Zasady raportowania..., s. 48-52].

\section{Dobre praktyki biznesowe na rzecz spójności społecznej}

W celu zidentyfikowania działań, jakie podejmuja przedsiębiorstwa w obszarze szeroko rozumianej SC, dokonano oceny dobrych praktyk zgłoszonych do raportu Odpowiedrialny biznes $w$ Polsce. Dobre praktyki 2016. Jest to najnowsze wydanie raportu z cyklu opracowań Forum Odpowiedzialnego Biznesu (FOB) $)^{9}$, stanowiące największy w Polsce przegląd społecznie odpowiedzialnych działań przedsiębiorstw w danym roku. Edycja raportu 2016 zawiera rekordowa liczbę 880 dobrych praktyk z zakresu CSR (zgłoszonych przez 180 firm), przypisanych z jednej strony do siedmiu kluczowych obszarów społecznej odpowiedzialności według ISO26000, a z drugiej do jednego z siedemnastu SDGs. Na potrzeby niniejszego artykułu dokonano przeglądu dobrych praktyk przyporządkowanych w raporcie do czterech z siedmiu kluczowych obszarów społecznej odpowiedzialności według ISO26000, dotyczaccych kwestii zwiazzanych z SC, tj.: praw człowieka, praktyk z zakresu pracy, zagadnień konsumenckich oraz zaangażowania społecznego

9 FOB jest to najdłużej działająca i największa organizacja pozarządowa w Polsce, która zajmuje się społeczną odpowiedzialnościa przedsiębiorstw w sposób kompleksowy, a także jest inicjatorem i partnerem przedsięwzięć kluczowych dla polskiego CSR. 
i rozwoju społeczności lokalnej. Analizie poddano 667 dobrych praktyk (w tym 325 długoletnich), zgłoszonych przez 267 firm - rysunek 2 .

RYSUNEK 2.

Liczba dobrych praktyk, zgłoszonych do czterech kluczowych obszarów społecznej odpowiedzialności ISO26000, dotyczących kwestii związanych ze spójnością społeczną

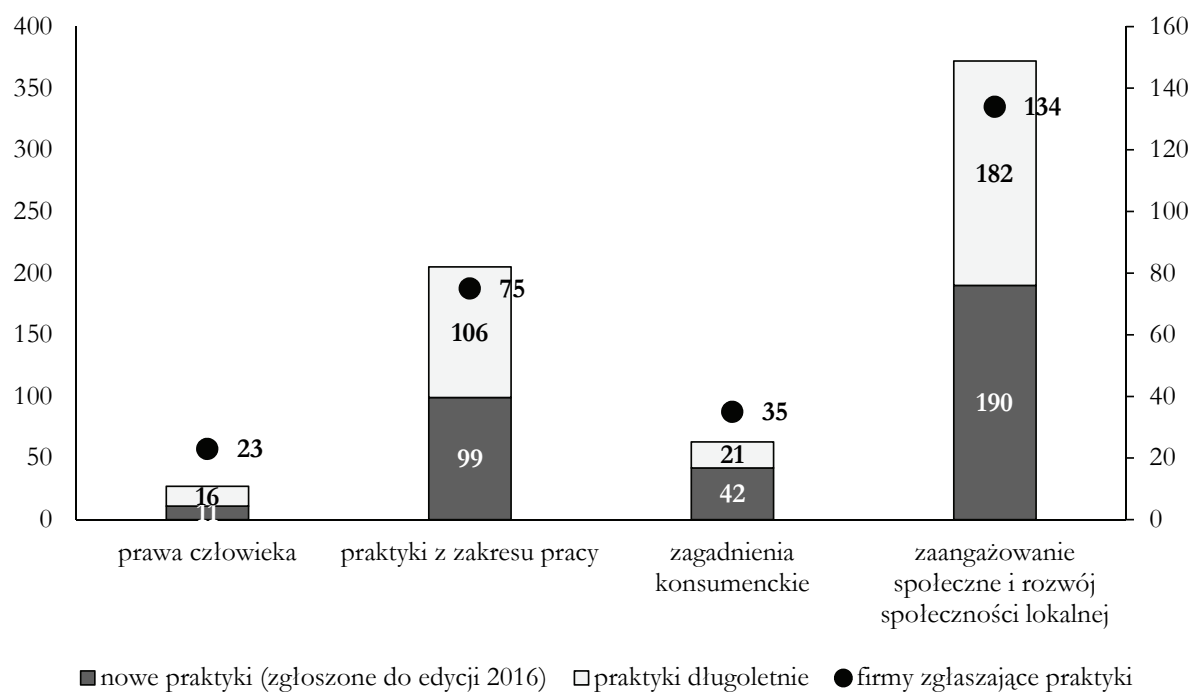

Źródło: opracowanie własne na podstawie: [Raport Odpowriedzialny..., 2017].

Przy ocenie 667 dobrych praktyk z czterech kluczowych obszarów społecznej odpowiedzialności ISO26000 brano pod uwagę to, czy dotyczą one którejś z kategorii składowych pojęcia SC w szerokim ujęciu (przedstawionych na rysunku 1.). Przeanalizowane praktyki przypisano do dziesięciu SDGs, obejmujących SC (kierując się przy tym 169 zadaniami, dedykowanymi poszczególnym SDGs). Część dobrych praktyk (41) odnosiła się do innych SDGs, niż te wybrane do badania.

W tabeli 1. przedstawiono macierz korelacji 626 dobrych praktyk, zgłoszonych do czterech kluczowych obszarów społecznej odpowiedzialności ISO26000 i przyporządkowanych do wybranych dziesięciu SDGs. Poszczególnym SDGs przypisano odpowiednie kategorie składowe SC, do których odnosiły się te cele (i dobre praktyki im przyporządkowane).

Warto podkreślić, że wiele dobrych praktyk wykraczało poza konkretny SDGs czy kluczowy obszar ISO26000, realizując cele czy przynosząc korzyści: wielowymiarowe, wielostronne i wieloaspektowe. Wszystkie jednak praktyki, z uwzględnionych w tabeli 1., w jakimś stopniu przyczyniały się do zwiększania SC. 


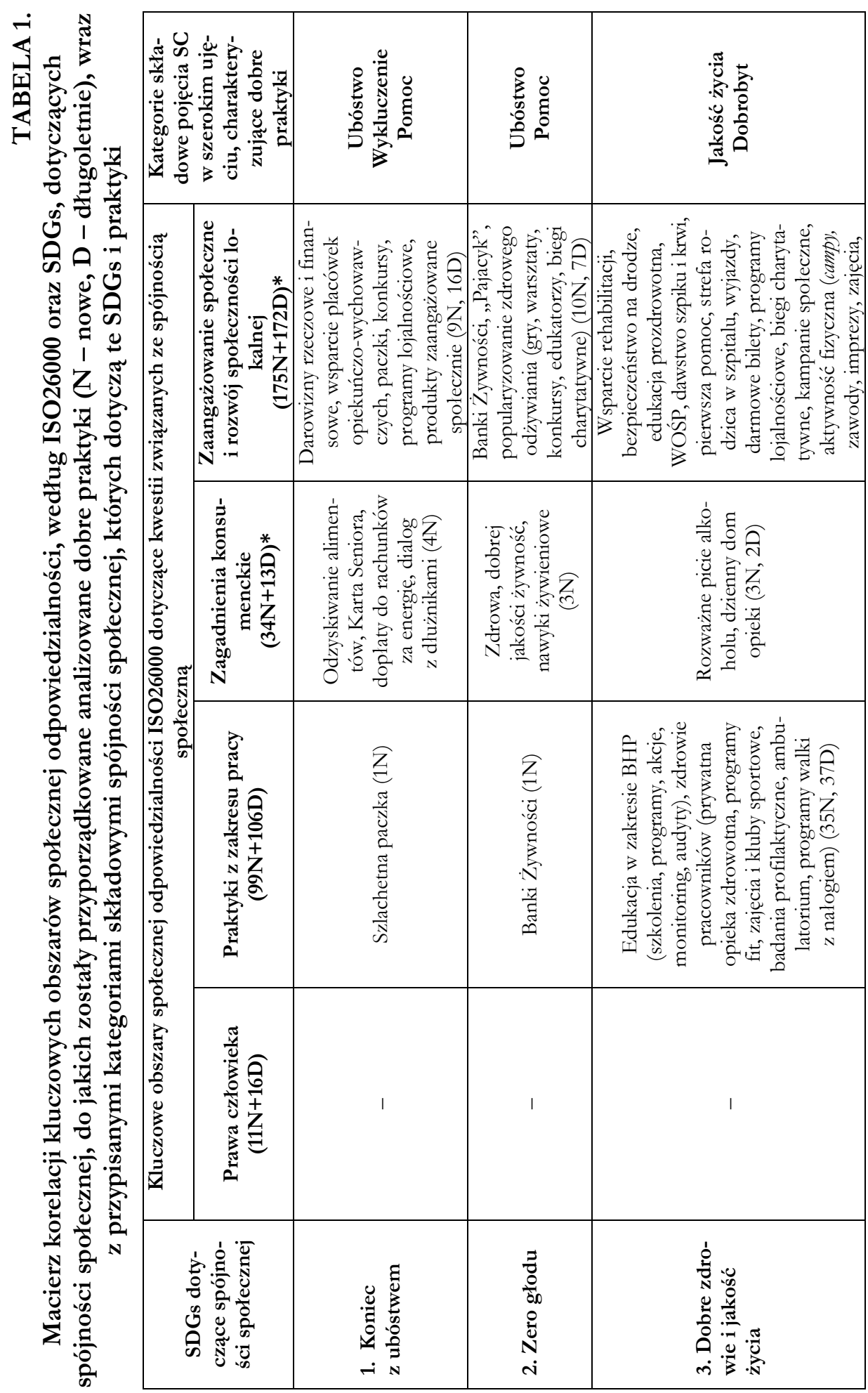




\begin{tabular}{|c|c|c|c|c|}
\hline & 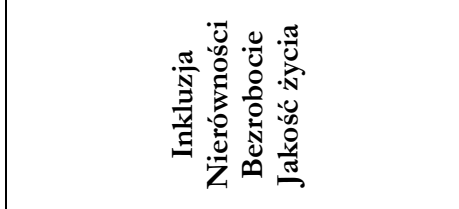 & 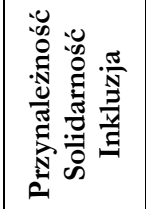 & 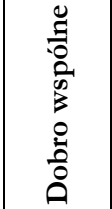 & 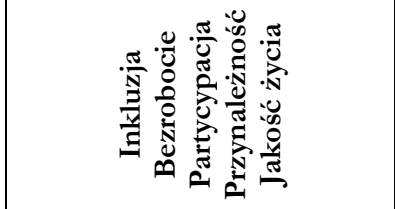 \\
\hline \multirow[t]{5}{*}{ 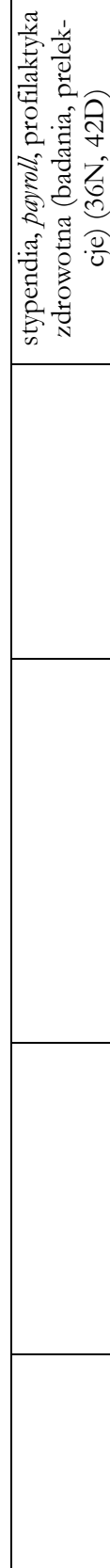 } & 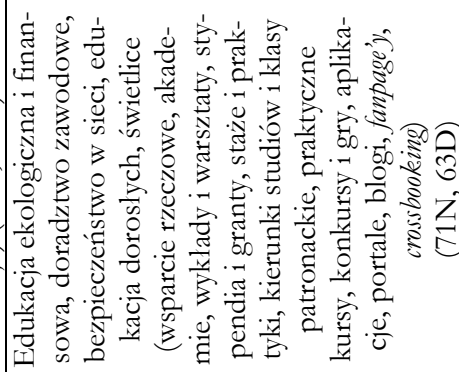 & 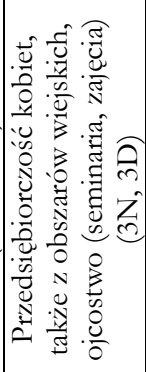 & 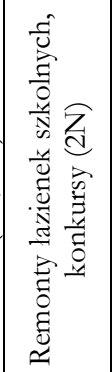 & 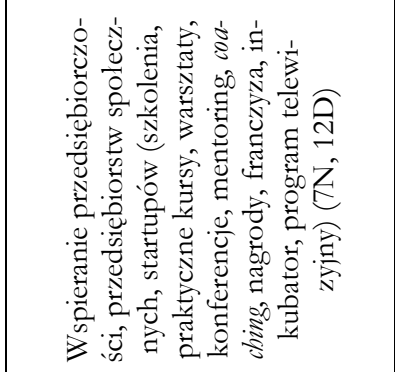 \\
\hline & 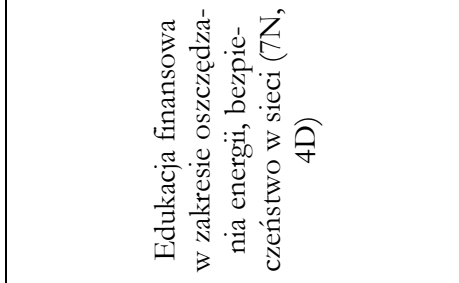 & 1 & 1 & 1 \\
\hline & 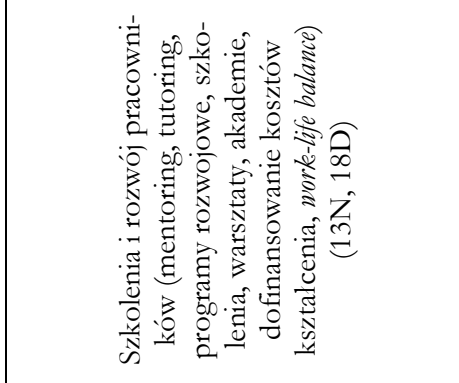 & 1 & 1 & 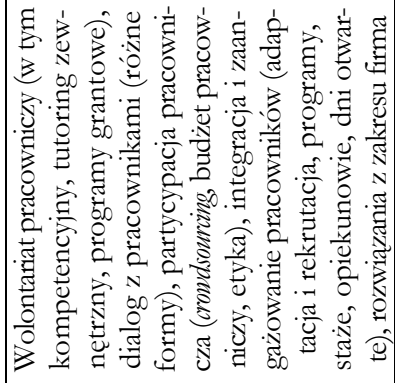 \\
\hline & 1 & 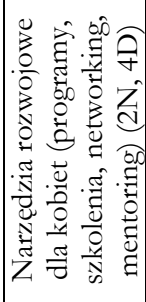 & 1 & 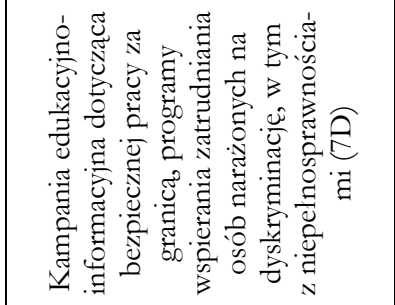 \\
\hline & 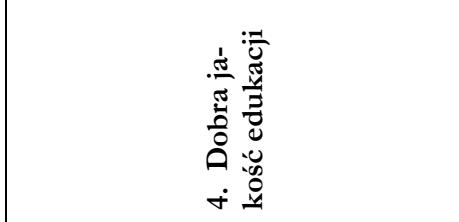 & 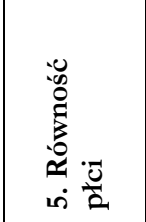 & 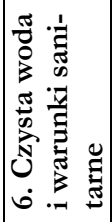 & 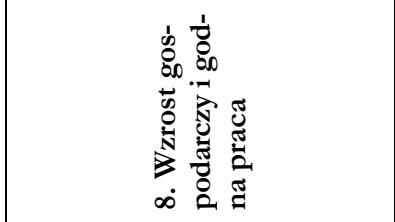 \\
\hline
\end{tabular}




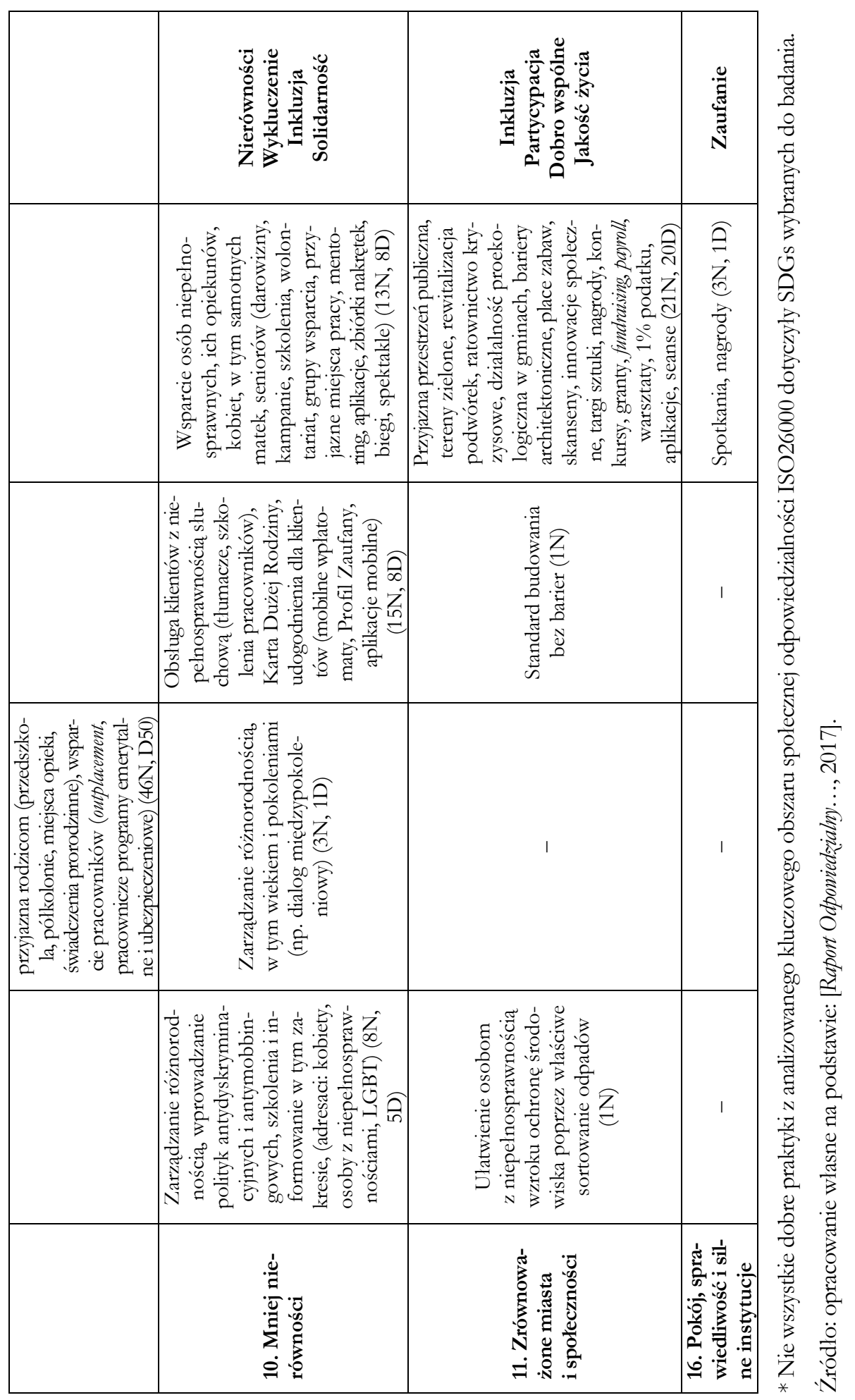


W obszarze praw człowieka dominują działania na rzecz zarządzania różnorodnością, w tym płci oraz włączającego zatrudnienia osób zagrożonych marginalizacją. Wszystkie z 27 zgłoszonych w tym obszarze praktyk w znacznym stopniu przyczyniają się do wzmacniania SC, ponieważ stanowi ona istotę obszaru praw człowieka. Wśród praktyk dotyczących zarządzania różnorodnością na uwage zasługuje kompleksowy program różnorodności Banku BGŻ BNP Paribas, w ramach którego firma rozwija wewnętrzną infrastrukturę w tym zakresie, wspierająca prowadzone (i monitorowane) działania na rzecz budowania świadomości wśród pracowników [Program Róźnorodności...]. Warto pokreślić, że Grupa BNP Paribas przyjęła Strategię CSR, w której różnorodność jest jednym z dwunastu zobowiązań. Strategia odwołuje się również do innych kwestii związanych z SC - rysunek 3 .

\section{RYSUNEK 3.}

\section{Strategia CSR Grupy PBN Paribas}

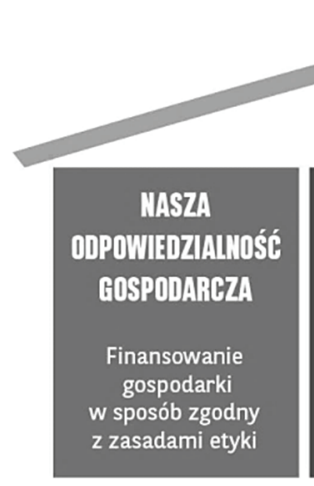

\section{FILARY I 12 ZOBOWIĄZAŃ ODPOWIEDZIALNEGO BANKU}
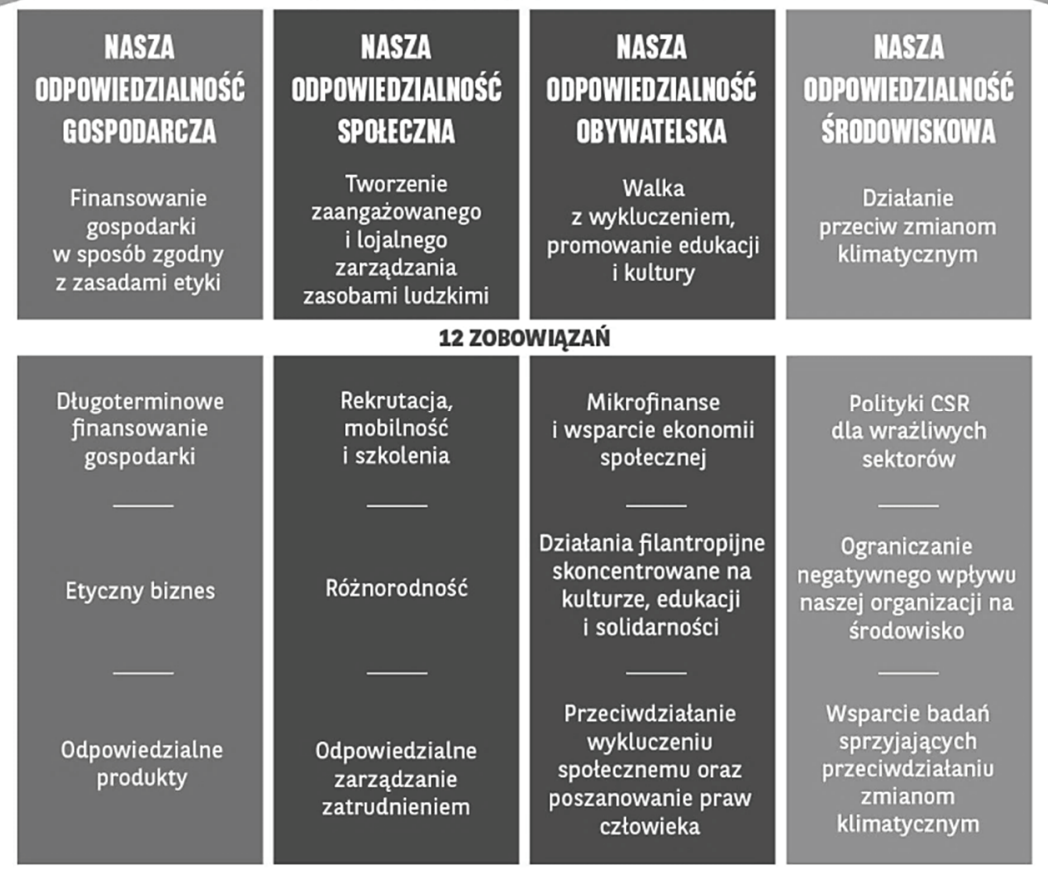

Stosowanie dobrych praktyk w tworzeniu ładu korporacyjnego

Źródło: [Społeczna odpowiedrialność...]. 
Cenna praktyką z tego obszaru, która stanowi innowację społeczną jest pionierski projekt ENERIS Surowce, w ramach którego firma produkuje specjalne naklejki umożliwiające osobom z niepełnosprawnością wzroku właściwe sortowanie odpadów [Segreguje...].

Obszar praktyk z zakresu pracy jest drugi pod względem liczebności zgłoszonych dobrych przykładów (205). W obszarze tym dominują działania związane z wolontariatem pracowniczym. Narzędzie to, wraz ze wzrostem świadomości firm co do wielorakich korzyści z niego płynących, przybiera coraz bardziej zinstytucjonalizowane formy. Drugim, najliczniej podejmowanym, tematem w ramach tego obszaru były zagadnienia związane z BHP oraz zdrowiem pracowników w szerszym wymiarze ${ }^{10}$. Trudno w obszarze praktyk z zakresu pracy wskazać jakąś szczególnie wyróżniająca się dobrą praktykę, czy to ze względu na jej kompleksowość, czy innowacyjność. Oceniając analizowane w tym obszarze praktyki z punktu widzenia wkładu na rzecz SC, należy uznać, że w najwyższym stopniu przyczyniają się do niej praktyki w zakresie wolontariatu pracowniczego, które przede wszystkim wspierają rozwój społeczności lokalnych, a także samych pracowników (poczucie wspólnoty, miękkie kompetencje). Wszelkie pozostałe działania, skierowane w stronę pracowników, bezpośrednio poprawiaja jakość życia tej grupy interesariuszy i jej rodzin.

W obszarze zagadnień konsumenckich część dobrych praktyk wpisywała się w inne, niż wybrane do analiz SDGs, tj. dotyczace odpowiedzialnej konsumpcji i produkcji, w tym partycypacji konsumentów, innowacyjności, czystej i dostępnej energii, życia pod woda (16 praktyk). Wśród pozostałych dobrych praktyk, uwzględnionych w tabeli 1., dominowały inicjatywy na rzecz zwiększenia dostępności produktów dla wszystkich konsumentów oraz edukacji finansowej, a zatem działania jak najbardziej przyczyniające się do zwiększenia SC. Pojawiły się również praktyki w różnorodny sposób zwalczające problem ubóstwa czy związane z odpowiednim odżywianiem. W kontekście jakości życia należy zarazem zwrócić uwagę na kilka praktyk dotyczących odpowiedzialnego spożywania alkoholu.

W obszarze zagadnień konsumenckich warto wyróżnić długoletnią praktykę Grupy BNP Paribas, która stworzyła Pakiet Społeczny Lider, czyli bezpłatne konto bankowe dla organizacji społecznych wraz z niezbędnymi usługami bankowymi i formalnościami ograniczonymi do minimum [Pakiet Społeczny...]. Od 2012 roku skorzystało z niego ponad 14 tys. organizacji [Raport Odpowiedrialny..., 2017, s. 87]. Jest to przykład działania, które nie tylko wspiera rozwój trzeciego sektora, tak istotny dla społeczeństwa obywatelskiego, lecz jednocześnie wpisuje się w podstawową działalność biznesową danej firmy (a takie społecznie odpowiedzialne działania stanowią największą wartość dodaną ze względu na know-how).

Obszar zaangażowania społecznego i rozwoju społeczności lokalnej zawiera największą liczbę dobrych praktyk (372), odnoszących się do kwestii SC we wszystkich wymiarach, jakich dotyczącą SDGs. Z tego powodu obszar ten jest najistotniejszy dla wzmacniania SC, a zawierające się w nim praktyki w najwyższym stopniu sprzyjają po-

10 Często praktyki BHP dotyczyły zdrowia w szerszym wymiarze, dlatego zaliczono je do działań w ramach celu 3., a nie celu 8. (godna praca). 
prawie jakości życia w różnych aspektach wielu grup interesariuszy. W obszarze zaangażowania społecznego i rozwoju społeczności lokalnej zdecydowanie dominowała praktyki z zakresu edukacji (134), przede wszystkim kierowanej do dzieci i młodzieży, także w kontekście wyrównywania ich szans ${ }^{11}$. Przeważały one nad kolejnymi w rankingu praktykami związanymi ze zdrowiem i jakością życia (78) oraz zrównoważonymi miastami i społecznościami (41), szczególnie ważnymi z punktu widzenia integracji społecznej. Część dobrych praktyk z tego obszaru (25) wpisała się w inne, niż analizowane SDGs (tj. dotyczące: odpowiedzialnej konsumpcji i produkcji, życia na lądzie, czystej i dostępnej energii, przemysłu i innowacyjności oraz partnerstw).

W tym obszarze jedną z dobrych praktyk, na które warto zwrócić uwage, jest bieg charytatywny PKO Banku Polskiego [Pomagamy...]. Z jednej strony, dlatego, że jest to instrument realizowania celów społecznych coraz częściej stosowany przez firmy, a z drugiej, ponieważ nie tylko służy zdrowemu stylowi życia, lecz również wspieraniu osób potrzebujących, budowaniu świadomości, wrażliwości i integracji społecznej.

\section{Podsumowanie}

Zgodnie z szeroką interpretacją SC jest definiowana nie tylko w kategoriach zmniejszania nierówności i wykluczenia, lecz także akceptacji różnorodności, współpracy, solidarności, dobra wspólnego i jakości życia. Jej istotą jest poprawa jakości życia dzięki tworzeniu poczucia wspólnoty w społeczeństwie.

Spójność społeczna jako pojęcie wielowymiarowe jest nie tylko coraz trudniejsza do uchwycenia (co wymaga rozwijania coraz bardziej rozbudowanych indeksów dla jej mierzenia), lecz także do osiagnięcia. Ostanie badania europejskie nawet dowodza, że w związu z narastającymi negatywnymi megatrendami, SC w wielu państwach zmniejsza się.

Zarówno „Agenda 2030”, jak i analizowane w artykule standardy CSR dostrzegaja istotną rolę biznesu we wdrażaniu rozwoju zrównoważonego, a tym samym - wpisującej się w ten paradygmat SC. Jak pokazuje analiza dobrych praktyk, zgłoszonych do raportu Odpowiedrialny biznes w Polsce. Dobre praktyki 2016, przedsiębiorstwa podejmują coraz więcej, coraz bardziej znaczących działań wspierających SC. Jednak konieczne jest przeprowadzenie dalszych badań, aby stwierdzić, czy działania te wynikaja z przyjętych przez przedsiębiorstwa strategii/polityk CSR, czy są raczej przypadkowe i niezamierzone (z punktu widzenia SC). Bowiem tylko celowe, skoordynowane i długofalowe działania na rzecz SC, najlepiej podejmowane w ramach współpracy międzysektorowej, $\mathrm{w}$ istotny sposób przyczynią się w istotny sposób do jej budowania.

Warto w tym kontekście podkreślić, że CSR jest koncepcją kompleksowa, wymagająca podejścia zintegrowanego, strategicznego (nieograniczającego się do aktywności w wybranym obszarze) dzięki temu rzeczywiście służącą tworzeniu wspólnej wartości (shared value) dla wszystkich interesariuszy [Porter, Kramer, 2011], w tym wzmac-

11 W przypadku praktyk z zakresu zaangażowania społecznego (w tym wolontariatu pojawiającego się także w obszarze praktyk z zakresu pracy) przypisywano je do poszczególnych SDGs, kierując się założeniami danej praktyki (np.: celem edukacyjnym, zdrowotnym). 
niania SC. Wyzwania, przed jakimi stoi współczesny świat, wymagają współodpowiedzialności i myślenia w dłuższej perspektywie. Natomiast SC, wiążąca się z: partycypacją, zaufaniem, więziami (a więc wysokim kapitałem społecznym), jest kluczowym warunkiem współdziałania także w biznesie.

\section{Literatura}

Cele i Zadania Zrómnoważonego Rozwoju, www.sdgs.pl/wp-content/uploads/2017/04/ sdgs_opis.pdf (data wejścia: 26.05.2017).

Chan J., To H.-P., Chan E., 2006, Reconsidering Social Cohesion: Developing a Definition and Analytical Framework for Empirical Research, "Social Indicators Research", no. 75.

Concerted Development of Social Cohesion Indicators. Methodological Guide, 2005, Council of Europe, Strasbourg.

Diagnoza spoteczna 2015. Warunki i jakość syycia Polakón. Raport, 2015, J. Czapiński, T. Panek (red.), Rada Monitoringu Społecznego, Warszawa.

Durkheim E., 2011, O podziale pracy społecznej, Wydawnictwo Naukowe PWN, Warszawa.

Elias N., 2008, Społeczeństwo jednostek, Wydawnictwo Naukowe PWN, Warszawa.

Gábos A., Goedemé T., 2016, The Europe 2020 social inclusion indicators: main conclusions of the ImPRovE project on validity, methodological robustness and interrelationships, "ImPRovE Working Papers", no. 13.

Golinowska S., 2011, O spójności i kapitale społecznym oraz europejskiej i polskiej polityce spójności, „Polityka Społeczna”, nr 5-6.

Greta M., Tomczak-Woźniak E., 2013, Problem spójności w nowej polityce regionalnej UE na lata 2014-2020, „Optimum. Studia Ekonomiczne”, nr 4 (64).

Human Development Report 2016: Human Development for Everyone, http:/ /hdr.undp.org/ sites/default/files/2016_human_development_report.pdf (data wejścia: 26.05.2017).

Jeannotte M. S. et al., 2002, Buying In Or Dropping Out: The Public Policy Implications Of Social Cohesion Research, http://www.researchgate.net/publication/237393749 BUYING_IN_OR_DROPPING_OUT_THE_PUBLIC_POLICY_IMPLICAT IONS_OF_SOCIAL_COHESION_RESEARCH (data wejścia: 26.05.2017).

Komunikat Komisji Europa 2020. Strategia na rzecz inteligentnego $i$ zrównoważonego rozwoju sprayjajacego właczeniu spotecznemu, $\operatorname{KOM}(2010), 2020$, wersja ostateczna, Bruksela, 03.03.2010.

Kosiel M. W., 2012, Spójność społecz̧na - definigje, unarunkowania, wskaźñiki i strategie w Unii Europejskiej oraz, Ameryce Lacińskiej, „Ameryka Lacińska”, nr 1 (75).

Krzyminiewska G., 2013, Nierówności a rozwój społeczny śniata, „Studia Ekonomiczne”, t. 139.

Nasza wspólna praysžłość. Raport Światowej Komisji do spraw Środowiska i Rozwoju, 1991, Polskie Wydawnictwo Ekonomiczne, Warszawa.

Norma PN-ISO 26000. Wytyczne dotyczace spotecznej odpowiedrialności, 2012, Polski Komitet Normalizacyjny, Warszawa. 
Pahl R. E., 1991, The search for social cohesion: from Durkheim to the European Commission, "European Journal of Sociology", vol. 32, Issue 2.

Pakiet Społeczny Lider, http://www.bgzbnpparibas.pl/male-firmy/pakiety-i-rachunki/ pakiet-spoleczny-lider (data wejścia: 26.05.2017).

Państwo w teorii i praktyce stosunków miedzynnarodonych, 2009, M. Sułek, J. Symonides (red.), Wydawnictwo Uniwersytetu Warszawskiego, Warszawa.

Papuć E., 2011, Jakość sycia - definicje i sposoby jej ujmowania, "Current Problems of Psychiatry", nr 12(2).

Poland, http://www.bertelsmann-stiftung.de/en/our-projects/social-cohesion/projecttopics/international-results/result-poland/(data wejścia: 26.05.2017).

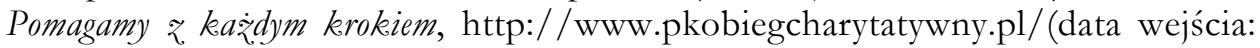
26.05.2017).

Porter M. E., Kramer M. R., 2011, Creating Shared Value, "Harvard Business Review", January-February.

Program Różnorodności w Banku BGŻ BNP Paribas, http://odpowiedzialnybiznes.pl/dobrepraktyki/program-roznorodnosci-banku-bgz-bnp-paribas/(data wejścia: 26.05.2017).

Przelesz̧ałcamy nasz świat: Agenda na rzecz zrównoważonego rozwoju 2030, 2015, Rezolucja przyjęta przez Zgromadzenie Ogólne w dniu 25 września 2015 roku.

Raport Odpowiedzialny biznes w Polsce 2016. Dobre praktyki, 2017, Forum Odpowiedzialnego Biznesu, Warszawa.

Rawls J., 2009, Teoria sprawiedliwości, Wydawnictwo Naukowe PWN, Warszawa

Revised list of global Sustainable Development Goal indicators, https:/ / unstats.un.org/sdgs/ indicators $/$ Official $\% 20$ Revised $\% 20$ List $\% 20 \mathrm{of} \% 20$ global $\% 20$ SDG $\% 20$ indicators.pdf (data wejścia: 26.05.2017).

Schraad-Tischler D., Schiller Ch., 2016, Social Justice in the EU - Index Report 2016. SocialInclusion Monitor Europe, Bertelsmann Stiftung.

Segreguje - nie widž przeszkód, http://grupa-eneris.pl/o-nas/zrownowazony-rozwoj/ segreguje-nie-widze-przeszkod/(data wejścia: 26.05.2017).

Social cohesion and well-being in the EU, 2014, Bertelsmann Stiftung, Eurofound.

Social Cohesion Radar. Measuring Common Ground, An International Comparison of Social Cohesion, http://www.bertelsmann-stiftung.de/fileadmin/files/BSt/Publikationen/Graue Publikationen/GP_Social_Cohesion_Radar.pdf (data wejścia: 26.05.2017).

Social cohesion, http://www.eurosocial-ii.eu/en/pagina/cohesion-social (data wejścia: 26.05.2017).

Społeczna odpowiedżialność biænnesu, http:www.bgzbnpparibas.pl/o-banku/spolecznaodpowiedzialnosc-biznesu (data wejścia: 26.05.2017).

Spónność społecżna, http://www.ekonomiaspoleczna.pl/x/629824 (data wejścia: 26.05.2017).

Stanley D., 2003, What Do We Know about Social Cohesion: The Research Perspective of the Federal Government's Social Cohesion Research Network, "The Canadian Journal of Sociology", vol. 28, no. 1.

Strategia na rzecz. Odpowiedzialnego Rozৃwoju do roku 2020 (z.perspektywa do 2030 r.), 2017, Ministerstwo Rozwoju, Warszawa.

The White Paper on multi-level governance, http://cor.europa.eu/en/activities/governance/ Documents/mlg-white-paper/0387_inside-en-last.pdf (data wejścia: 26.05.2017). 
Waldziński D., 2008, Spójnośc ekonomiczna Unii Europejskiej w świetle wspótczesnych præermian kulturowo-cywilizacyjnych, [w:] Spójność spotecżna, ekonomiczna i terytorialna w polityce Unii Europejskiej, E. Pancer-Cybulska (red.), Prace Naukowe Uniwersytetu Ekonomicznego we Wrocławiu nr 28, Wydawnictwo Uniwersytetu Ekonomicznego, Wrocław.

Zasady raportowania i wskaźniki. G4. Wytyczne dotyczace raportowania, http://www.globalreporting.org/ resourcelibrary/Polish-G4-Part-One.pdf (data wejścia: 26.05.2017). 